Leslie Bussert

\title{
Comic books and graphic novels Digital resources for an evolving form of art and literature
}

\section{"Holy Hyperlinks, Batman!"}

Comic books and graphic novels are becoming two of the most pervasive and in uential media forms of popular culture. Placed within the context of changing society, comic books and graphic novels entertain and educate, but they have also been instrumental in documenting and interpreting social, historical, and current events.

Scholarship and research surrounding comic books and graphic novels are growing. Many in the elds of history, sociology, and arts and literature realize the unique and valuable insight inherent in studying comic books and graphic novels. Thus, new collections and resources are being created and developed to meet the needs of fans, collectors, scholars, and researchers alike.

With numerous comic book and graphic novel Internet resources today, it is challenging to identify those frequently updated or professionally maintained; many lack organization but contain authoritative content. While the list provided here is not comprehensive, librarians should nd these resources valuable in getting acquainted with the genres, making selections for their collections, and assisting users seeking comic book or graphic novel resources.

\section{Starting points: research guides}

Comic Books: Internet Resources.

This research guide contains annotated online comic book resources compiled by Michael Lavin, Arts and Sciences Librarian at the University of New York at Buffalo. Categories include Internet portals and guides, news and previews, magazines and journals, his- tory, and bibliographies. Sections of particular interest to librarians include commentary and reviews, collection development tools, recommendations for libraries, and resources for teachers. Access: http://ublib.buffalo.edu/ libraries/asl/guides/comics.html.

- Comic Books, New York Public Library (NYPL), General Research Division at the Humanities and Social Sciences Library. In addition to describing the NYPL s comic book collection, this research guide offers tips for searching the catalog for comics and links to related collections or Internet sites. Valuable bibliographies are offered for general comics research, history and criticism, and more. Access: http://www.nypl. org/research/chss/grd/resguides/comic.

Yale University Library's Comic Books, Comic Strips, and Graphic Novels Research Guide. From Yale University Library s Mass Media and Popular Culture research guide, this site offers suggested LC Subject Headings for searching library catalogs, print and online research sources, and links to comic book and graphic novel publishers and distributors. International in scope, there are over 30 research sources covering comic strips, comic books, graphic novels, and more. Access: http://www.library. yale.edu/humanities/media/comics.html.

\section{News and reviews}

ArtBomb. Brainchild of acclaimed writer

Leslie Bussert is reference/instruction and ethics/ humanities librarian at the University of WashingtonBothell and Cascadia Community College library, e-mail: Ibussert@uwb.edu.

(c) 2005 Leslie Bussert 
Warren Ellis and Internet producer Peter Siegel, ArtBomb aims to broaden the appeal of comic

\section{ARTBOMB.NET \\ A GRAPHIC NOYEL EXPLOSION. PULL THE PIN}

books and graphic novels through promoting and reviewing diverse and sophisticated titles. Reviews may be searched by creator, title, or genre, and some include previews. This site also offers a What is a graphic novel? introductory tour in comic book format aimed at librarians, educators, and new fans. Access: http://www.artbomb.net.

Comic Book Resources. This popular site offers numerous resources for any level of comic book fan. Daily news within the comic book industry regarding writers, artists,

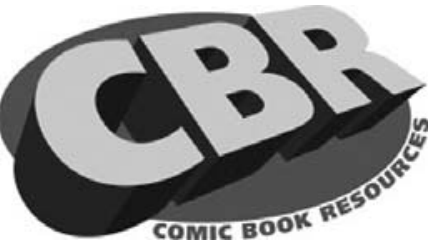
characters, series, and corporate activities is covered. Featured articles include artist and writer interviews or full-length articles, while columns feature opinion and editorial pieces, gossip and rumors, commentary, reviews, and satire. Archives are sparse, but they go back to 1998. Access: http://www.comicbookresources.com.

- Comics Continuum. A very straightforward site offering up-to-date breaking industry news including publication information, $1 \mathrm{~m}$ projects, writer and artist contracts, sales trends, and new issue previews. Archives go back about three weeks. Access: http://www.comicscontinuum.com.

Comics Worth Reading. This site provides industry news, reviews, and extensive recommendations for manga, independent, DC Comics, and Marvel Comics titles and series. Reviews include publishing history, art samples, plot summaries, and Web links. The author has been reviewing comics for over 10 years and highlights women s roles within the comic book and graphic novel industry, whether they are characters, writers, artists, or editors. Information about how to review comics is also available. Access: http://www. comicsworthreading.com.

- Newsarama. Updated several times daily, this site offers breaking industry news, features, previews, reviews, and opinions and editorials in discussion board format so readers may directly respond to posted items. Comic book and graphic novel reviews and previews are posted by the contributing editors as well as readers. Archives go back a few days. Access: http://www.newsarama.com.

\section{Organizations and associations}

- Comic Book Legal Defense Fund (CBLDF). Aimed at preserving First Amendment rights for members of the comics community, the CBLDF s Web site offers news, featured links, convention previews, and reports raising awareness of censorship issues within the comic industry. Additional resources include a comic censorship bibliography highlighting articles, books, and case les for which the CBLDF has helped defend over the years, and a comic censorship timeline beginning in the 1750s. Access: http://www.cbldf.org

- International Comic Arts Association (ICAA). A nonpro $t$ organization, the ICAA aims to support, promote, and strengthen the comic industry, its products, and professionals through a variety of programs and projects. Their Web site offers industry and organizational news, interview and article features (coming soon), and resources for retailers, libraries, teachers, creators, collectors, and fans. Access: http://www.comicarts. org/index.php.

National Association of Comic Arts Educators (NACAE). Committed to helping facilitate the teaching of comics in higher education, the NACAE site contains resources for individuals and institutions interested in teaching visual storytelling. Their site offers a forum where educators in comic and/or sequential art can get and share ideas. Resources include articles, teaching resources (exercises, study guides, syllabi, handouts, etc.), message boards, and more. Access: http://www.teachingcomics.org. 


\section{Bibliographies and collections}

Comic Books, Library of Congress

Popular Culture Collections, Serials \& Government Publications Division. Both

foreign and U.S. titles make up this largest collection of comic books in the United States. The collection includes scattered issues or microforms back to the 1930s but is mostly comprehensive from 1950 on. This site provides information for using and researching the collection including suggested techniques and subject headings. Access: http://memory. loc.gov/ammem/awhhtml/awser2/comic_ books.html.

Comics-Related Dissertations and Theses. This site provides an international bibliography of doctoral, master s, and undergraduate dissertations and theses going back to the 1970s. Many entries provide abstracts or annotations and links to tables of contents or the full text. Access: http://home.earthlink. net/\%7Ecomicsresearch/ComicsDissertations. html.

Comics Reporter's Books about Comics Bibliography. International in scope, this bibliography contains numerous entries of books about comics, particularly those with an emphasis on criticism and history. Entries are in alphabetical order by title, and coverage goes back to the 1950s. Access: http://www.comicsreporter.com/index. php/lists/lists_and_links/87.

- Comics Scholarship Annotated Bibliographies (SCAB). This site offers annotated bibliographies covering book-length works about comic books and strips ranging from fannish histories to academic publications. Bibliographies are divided by subject categories such as genre, guides, countries, collecting, and more. Additionally, tables of contents, lists of comic works within the title, reviews, links, and other general notes on content and organization are included. Access: http://www.comicsresearch.org.

Michigan State University (MSU) Comic Art Collection. With over 200,000 items mostly comic books the MSU Comic Art Collection is known as the primary library resource for the study of U.S. comic book publications. In addition to descriptions of the collection, multiple indexes, selected images, the collection development statement, and a list of other comic research collections are offered. Access: http://www.lib.msu. edu/comics.

- Museum of Comic and Cartoon Art (MOCCA). The purpose of this museum is the collection, preservation, study, education, and display of comic and cartoon art. Genres treated include animation, cartoons, comic books and strips, graphic novels, and more. MOCCA s Web site offers information and news about the

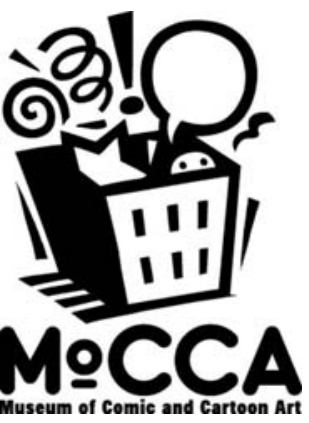
organization, but also past and present exhibit information, upcoming events, and features including interviews and legal or educational information. Access: http://www.moccany. org.

New York City Comic Museum (NYCCM). Founded in 1999, the NYCCM promotes comic book history, preservation, and literacy through its collections and Web site. The site offers online exhibits with ar-

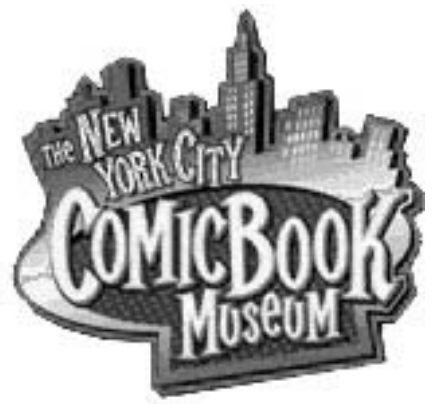
chives, resource links, an education center with lesson ideas, and guides for bringing comic books into the curriculum. Also included are columns and current museum news. Access: http://www. nyccomicbookmuseum.org/main.htm.

\section{Online magazines and journals}

- ImageTexT. A Web-based journal with free access to all articles, ImageTexT strives to advance the academic study of comic books and strips, cartoons, and other media blending image and text such as video games. Topical issues contain peer-reviewed articles, reviews of current scholarship in the eld, conference or publication announce- 


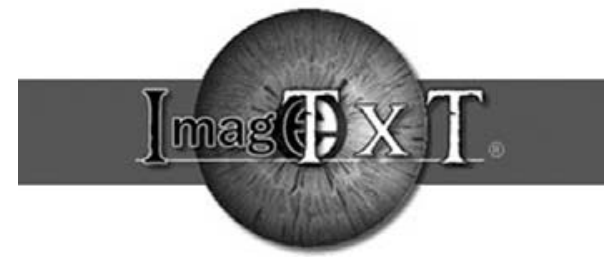

ments, information on research projects of interest, and English translations of seminal foreign essays on comic theory. Current and archived issues and online exhibits with catalogs are also available. Access: http://www. english.u .edu/imagetext.

- Indy Magazine. Published by Alternative Comics, this online journal offers feature articles, reviews, and news about independently published comic books and graphic novels. Contributors are diverse, coming from the U.S., Canada, Great Britain, and France. Archives of older issues are available. Access: http://www.indyworld.com/indy.

Ninth Art. A weekly online journal, Ninth Art strives to provide a space for an expanding repository of ideas, analysis, and contemporary thought through exploring every aspect of the arts and industry of comics. Operating without editorial agenda,

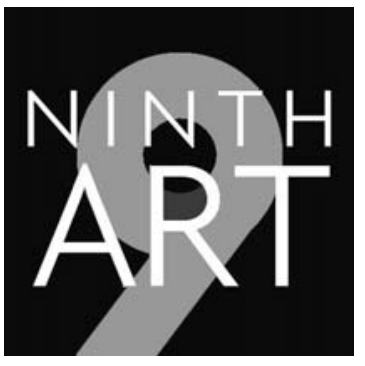
articles, essays, reviews, and interviews published are written with high standards. Four new articles per week are published, and archives, message boards, and RSS feeds are available. Access: http://www.ninthart.com.

\section{Reference tools and resources}

Comic Art in Scholarly Writing: A

Citation Guide. Recognizing the maturation of comic scholarship and the need for comic bibliographic citation formats, Allen Ellis, research and instructional services librarian at Northern Kentucky University, created this guide in accordance with the Comic Art and Comics area of the Popular Culture Association. The online style guide offers instructions and numerous examples for citing comic books, comic strips, editorial cartoons, and graphic novels. Access: http://www.comicsresearch.org/CAC/cite.html.
- Grand Comic Book Database. Searchable by writer, artist, title and publisher, this database offers records for over 70,000 issues of comic books, minicomics, and fanzines. Entries are indexed by site owners, fans, or hobbyists, using detailed and speci c instructions to ensure consistency and quality of records. Entries include a color image of the cover, information about the binding, ink, paper type, publisher, run dates, issues published, and language; also provided are links to other indexed issues of the title. Access: http://www.comics.org.

Who's Who of American Comic Books. This resource provides biographical listings for over 19,000 artists, writers, editors, and personnel involved in producing comics.

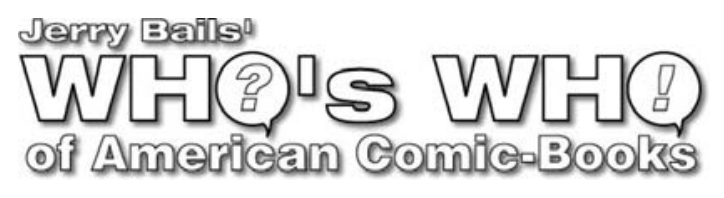

Publishing groups are also included, with listings for animation, syndication, small presses, pulps, and more. Researchers and writers may inquire for speci $\mathrm{c}$ data by e-mailing the site author, but full paid subscriptions are also available. Additional site content includes a list of artist aliases and a complete index of titles published. Access: http://www.nosotomo.no/whoswho.

\section{Of particular interest to librarians}

Comic Scholars Discussion List.

This community is aimed at those involved in research, criticism, and teaching related to comic art. Welcome to all academic elds, typical discussion revolves around theoretical and historical issues, syllabi and assignments, useful scholarship or resources, and calls for book, journal, and conference submissions. It is also a place to discuss job searches, pedagogy, library acquisitions, and other institutional factors affecting comics scholarship. The list s Web site includes a directory of comic scholars, online sample syllabi, bibliographies, and more. Access: http://www. english.u .edu/comics/scholars.

(continued on page 113) 
the Library administration won t really know how the new hire is adjusting.

Performance appraisal. Clearly state what the criteria for evaluation are going to be so there are no misunderstandings later. An actual copy of the appraisal form is an excellent tool for the employee to refer to so there will be no surprises.

In librarianship, while poor orientation experiences most likely outnumber good orientation experiences, it is a factor in employee longevity and morale. An employee that has not experienced a real orientation may feel alienated and resentful; they might even leave the organization when a serious opportunity arises. Another problem, if they stay they may become a disrupting/negative force within the staff. ${ }^{4}$

Although what has been provided in this article is by no means a comprehensive list, items listed will help in the successful transition from new hire to long-term contributing employee. The use of a checklist is advisable due to the numerous details one must remember.

While it is dif cult to nd a good candidate and then hire that individual, it is very easy to ruin what may be a long and productive professional relationship in the rst few days by innocently forgetting some small detail. The investment of making a new employee feel welcome will help them to identify with the institution, the orientation process often stresses the why. ${ }^{5}$

\section{Notes}

1. Jean Dowdall. Off to a good start: Thoughts on the rst weeks of a new job, Chronicle of Higher Education Monday, July 1, 2002. chronicle.com/jobs/2002/07/ 2002070101c.htm.

2. Stacey E. Kimmel and Scott R. DiMarco, Planning an interview: What do candidates want? CERL News 58, no.4 (1997):249 50+.

3. The Society of the Plastics Industry. The high cost of employee turnover. www.plasticsindustry.org/business/programs/orientme. htm (accessed March 19, 2004).

4. Joyce Gioia, Use Orientation Process to Bond with New Employees HR Focus 76, i6. (1999) is9.

5. Randall L. Robbins, Orientation: Necessity or Nightmare? American Salesman 47, i9 (2002):29. $\pi$

("Comic books..." continued from page 106)

Graphic Novels in Libraries (GNLIB-

L). This unmoderated community is limited to professionals in the book trade and librarians and is speci cally aimed at young adult and adult services public librarians. GNLIB-L is a space to share reviews, ideas, and resources for the selection and development of graphic novel and comic book collections. Membership is not required to view the archives. $A c$ cess: http://www.topica.com/lists/GNLIB-L.

Librarians in Comics. Maintained by Canadian librarian Steven Bergson, this site contains an annotated bibliography of books, comic books, and graphic novels in which a librarian or library plays a role. A bibliography for librarians in comic strips is also available. Access: http://www.geocities.com/Athens/ Acropolis/2161/combks/combks.htm.

- No Flying, No Tights. Created and maintained by library technician and MLSholder Robin Brenner and friends, this resource contains three comic book and graphic novel review sites, one each for kids, teens, and adults. Each includes core lists of recommended and reviewed titles divided into various topics, with some aimed at librarians and teachers. Aside from genre divisions, indexes for creator, title, and publisher offer great search tools for nding reviews. Access: http://www.no yingnotights.com. $\approx$ 